\title{
ENHANCING THE STUDENTS' SPEAKING SKILL IN SPEAKING CLASS PROGRAM THROUGH ROLE PLAY AT SENIOR HIGH SCHOOL
}

\author{
Henry Elisa \\ STKIP Persada Khatulistiwa Sintang \\ henryelisa.edu@gmail.com
}

\begin{abstract}
The objectives of this study were to describe the impact, strengths and weaknesses of role play in the teaching and learning process among the tenth grades students at Senior High School in Kalasan, Sleman. This study applied qualitative research. The subjects of the study were an English Teacher for Speaking Class Program and students of class XB. Techniques for collecting data for the study were observation, document review and interview. Data collection tools of the study were recorder and interview guidelines. The results of the study proved that role play has improved the teaching and learning process in speaking class program for the tenth grade students at Senior High School. The strengths of this technique in the process of teaching and learning was the teacher can bring the social situation into the classroom and the student can have new experiences in learning language by play a certain role in the speaking activity. During the process of learning, the students would be pay attention to the other students who were performed in front of the classroom and they may tried to find a way to improved their performance when their turn to perform or play the role they have got from the teachers.
\end{abstract}

Keywords: teaching technique, role play, speaking class

\section{INTRODUCTION}

Speaking skill must be mastered by learners. The target in teaching speaking skill is the learners able to speak English fluently and interactively. But in fact when the process of teaching speaking the teacher usually cannot make the students engage in the learning process actively. The learners only listen what the teacher said in the classroom. It is very poor for the learners because they cannot develop their ability in learning process. In brief, English teacher should be creative in developing their teaching and learning process to create good atmosphere, develop the students speaking skill.

One of the techniques that can be applied in teaching speaking is role play. The students would be asked to play characters based on the topic that is given to them. The objective of this activity is enhanced the student's competence in learning speaking. Through this activity, the students were free to develop their imagination and speak up without considering it with a set of patterns.

Role play can help the teacher expand the classroom indefinitely and provide natural contexts for the language used. The students get the chance to express themselves in a more forthright way, the world of the class is broadened to include the outside world-thus offering a much wider range of language opportunities and the last, it is useful to extend knowledge into feeling. 
This technique is chosen by the researcher after conducted pre observation and found that about a half of the number students in the classroom still inactive in the process of learning process. They were not able to give more responses when the teacher let them to interact by using English in the classroom. Most of them were also not confident when they were asked to practice in using English in the learning process and for classroom interaction.

From the background, the writer needs to limit the broad problem areas in order to have distinctive focus. In this research the writer wants to describe the process of teaching learning process using role play, and the strength and weaknesses of teaching speaking through role play among the tenth grade students at State Senior High School 1 Kalasan, Sleman. Based on the background, identification and limitation of the problem above, the research problem can be formulated as follows: 1 . How is the process of teaching speaking through role play to improve the studentse speaking skill at State Senior High School 1 Kalasan, Sleman? 2. What are the strengths of teaching speaking through role play among the tenth grade students at State Senior High School 1 Kalasan, Sleman?

According to the formulation of the problem above, the objective of the research are as follows: 1). To describe the teaching learning process of speaking through role play among the tenth grade students of State Senior High School 1 Kalasan, Sleman. 2). To describe the strengths of teaching speaking through role play among the tenth grade students at State Senior High School 1 Kalasan, Sleman.

\section{METHOD}

The researcher applied qualitative research in this study. Qualitative research is the research which does not use statistic data. It is associated to hypothesis generating and developing an understanding. Qualitative research collects the data through observation and then comes up with a theory. The theories can explain the data collected or the facts which are observed (Moleong, 1995: 2-7). Fraenkel and Wallen (1993: 383) also states that in data collection, the researcher is continually observing people, events, and occurrences, often supplementing his or her observations with in-depth interviews of selected participants and the examination of various documents and records relevant to the phenomenon of interest.

In data collection the researcher used observation, documentation review and interview. The researcher observes the teaching learning process of speaking ability in the classroom. Observation is a technique that involves systematically selecting, watching and recording behavior and characteristics of living being, objects or phenomena. Hornby (2000: 910) defines an observation as the act of watching somebody or something carefully for a period of time, especially to learn something. Further, Best (1976: 182) quoted that observation as a research 
technique must always be expert, directed by a specific purpose, systematic, carefully focused, thoroughly recorded.

The second technique of data collection was document review. It is a way of collecting data by reviewing existing documents. The documents may be internal to a program or organization, such as curriculum, syllabus, lesson plan, textbook, test, etc. or may be external such as literature of the data. Documents may be hard copy or electronic and may include reports, program logs, performance rating, meeting minutes, and newsletter, (Evaluation Briefs, No. 18/ January 2009). In this research the researcher reviewed the students' answer sheet that they used to make a dialogue before they perform or play the role in learning speaking activities.

And the third technique was interview. It is a data collection that involves oral questioning of respondents, either individually or as groups. According to Boyce and Neale (2006: 3), in dept-interviewing is a qualitative research technique that involves conducting intensive individual interviews with a small number of respondents to explore their perspectives on a particular idea, program, or situation. Further, Hornby (2000: 712) stated that interview is a formal meeting at which somebody is asked questions to see if they are suitable for a particular job, or for a course of study at a college, university, etc.

There were two kind tools of data collection used by the researcher. The first was digital camera to record the classroom activities of teaching learning process through role play. He recorded the learning activities from the back of the classroom. And the second was Interview guideline. It is used by the writer in order to get information from the teacher about the way in the teaching of speaking, and also for the students to get information about the speaking activities that they have got in the classroom.

This study was conducted from July 2011 to Januari 2012 among the tenth grade students of Senior High School 1 Kalasan, Sleman. In this time is used for preparation, data collection, data analysis, and reporting. The populations of the research were the tenth grade students of class XC of Senior High School 1 Kalasan. According to Arikunto (2002: 108), population is defined as all members of research subject or all of the members of the group of people, events or things to which generalization that are going to be involved in a research. The population is meant as the general stereotype classification of subject being studied.

While, the sample used in this research refers to what is suggested by Arikunto (2002: 112). Arikunto stated that if the subject of the research is less than 100, it is better to take the entire subject. If the subjects of the research are more than 100 , the 
writer can take $10 \%-25 \%$ of the population considering the limitation faced by the researcher in energy, fund or time. There are seven classes in the first year of Senior High School 1 Kalasan, Sleman. The total number of students is 224 , in which every class consists of 32 students. Although, there are seven classes but only one class was chosen to be the subject of the study. From the parallel classes, the writer took the observation focus on the class XC.

The reason of choosing these classes was due to their low participation in classroom when the teacher used regular methods and techniques. Besides, these classes seem to have problems in speaking. Therefore, it was very possible to make it as the subject of the research.

\section{FINDING AND DISCUSSION}

In the teaching of speaking to the tenth grade students in the senior Highs School 1 Kalasan, the English teacher develop the material for teaching based on the curriculum 2006 and syllabus. The contents of the syllabus are standard competence, basic competence, material, activity, indicator, assessment, time allocation and resource. She also makes a Lesson Plan as the guide in the teaching process.

Based on, the transcript of the interview with the English teacher conducted by the writer on Friday, August 19th, 2011. It can be concluded that: She uses electronic media such as LCD projector, and computer to show the material in power point format, video and $\mathrm{mp} 3$ for teaching. Sometimes, she also use conventional media such as students' paper work, board marker and white board. She used scripted role play in teaching speaking in her English Conversation (EC) class among the tenth grade students. It almost the same as dialogue, where the teacher prepares an example of dialogue, then asks students to play one of the characters in the dialogue. The difference between dialogue and scripted role play is that when students were asked to use dialogue, they only read the dialog but in scripted role play they will play a part of dialogue such as taking a position one of the characters.

The English teacher usually asks her students to make a group consisting of four to six students and sometimes in pairs when she gives the exercise to make a dialogue or conversation. She looks for some interesting topics to motivate her students in the class. So, they would be able to explore their imaginations to play part of the character in the scripted role play. Some interesting topics which are possible to teach are, such as the invitation to have dinner, at the department store, go to cinema, and holiday. 
Based on the results of the observation above, the writer concluded that the application of role play in teaching speaking was conducted in four stages got positive impacts. It means that the students understood the material and the process of teaching and learning ran well. It could be seen by seeing the students' participation in all of the steps conducted by the teacher in the first meeting.

In the BKOF part, the teacher introduced the material that would be given to the students. The teacher began teaching the students by asking stimulating questions to the students. The teacher showed a picture on the view screen. It was aimed to stimulate and introduce the topic to the students. Then, in the second steps, MOT (Modeling of Text) the writer gave some activities. Here, the students were able to answer the teacher' questions related to the picture shown on the view screen. They were also good enough in repeating the pronunciation of the dialogue and the vocabulary by modeling. The next evidence, the students showed a good participation in answering the teacher"s questions about the expressions in the dialogues given to them. In the third phase, that was JCOT (Join Construction of Text), the students showed a good participation and also cooperation in the session. They made and practiced their own dialogue well in front of the classroom when the teacher called them to perform it in pairs. And, in ICOT (Individual Construction of Text), the last activity, the students still responded the teacher's instruction to do an assignment in the classroom and then as their homework because of limited time.

The English teacher of class XC made some preparations before conducting the teaching of speaking through role play. The preparations are as follows: Teacher made a lesson plan as the guide to conduct the teaching learning process. She gave a model of dialogue to the students. Then, she introduced some expressions and gave model of pronunciation of the dialogue. Then, she asked the students to repeat it.

After that, she asked the students to do a task in pairs. They were asked to change the dialogue based on the situation which is given to them. After that, they are called to practice the role play at the front. They brought their cellular phone when practiced it because they played a role of two characters in the scripted role play of the dialogue by phone. They did it in pairs because in the scripted role play has two characters, and they prepared the dialogue at home because the time was not enough to make it in the class.

\section{CONCLUSION}

From the explanation above we can see the most important key in building students' communicative competence which leads to speaking ability is taking them into the real use of 
English, providing them with exposure of frequent use of English and giving them chance to show their ability in speaking.

The strengths of teaching speaking through role play are as follows: the first, teacher can bring the social condition to the classroom, where the students are asked to play a role. This offers a much wider range of language opportunities. So, the students can be anyone and any situation they wish. The second, the use of role play makes the speaking and learning activity more enjoyable and interesting, because the situation that is given to the students is related to their daily life situation. And the last, the use of scripted role play makes the class more active, motivated, and alive. Students are willing to participate without any forces from the teacher. $\mathrm{d}$. In learning process through role play the students have a chance to express their thought by writing a dialogue using some expressions they have learnt.

Teaching speaking skill considers many aspects. They are teaching method and techniques, the students, teaching aids (media), instructional materials, and appropriate tasks. The findings of this research are expected to help the teachers to improve students' speaking skills through applying role play in the classroom. Also, by applying the role play in the classroom, it is able to improve the teacher's competencies in teaching. However, the teachers still need a lot of practices in using various techniques for teaching speaking, besides questions and answer, and dialogues.

Furthermore, the teacher needs to improve her teaching competence in the teaching of speaking through role play. The teacher needs to explain more situations for the role play, so that the students are able to understand how to create the dialogue for role play well.

\section{REFERENCES}

Arikunto, Suharsimi. 2002. Prosedur Penelitian: Suatu Pendekatan Praktek, Edisi Revisi V. Jakarta: Rineka Cipta

Best, John W. 1976. Research in Education. New Hersey: Prentice Hall Inc. Englewood Cliffs. Boyce, Carolyn and Neale, palena. 2006. Conducting In-Depth Interviews: A Guide for Designing In-Depth Interviews for Evaluation Input. Pathfinder International

Fraenkel, Jack R. and Wallen, Norman E. 1993. How to Design Evaluate Research in Education. New York: McGraw-Hill Inc.

Hornby, A.S. 1995. Oxford Advanced Learners' Dictionary. New York: Longman Publishing Moleong, Lexy J. 1995. Metodologi Penelitian Kualitatif. Bandung: Remaja Posdakarya 